\title{
Evaluation and toxicological quantification of undeclared allopathics and adulterated synthetic steroids in herbal antihypertensive preparations
}

\author{
Muhammad Asif Khan ${ }^{1 *}$, Amir Badshah ${ }^{1}$, Jahangir Khan ${ }^{2}$, Faryal Liaqat $\mathrm{Ali}^{3}$ \\ ${ }^{1}$ Department of Pharmacy, University of Peshawar, Peshawar 25120, ${ }^{2}$ Department of Pharmacy, University of Malakand, \\ Chakdara, ${ }^{3}$ Department of Pharmacy, Sarhad University, Peshawar, Pakistan
}

*For correspondence: Email: muhammadasifkhan.263@gmail.com; Tel: +92-301-808-7473

\begin{abstract}
Purpose: To evaluate raw and finished dosage form of herbal antihypertensives for quantification of undeclared allopathic contents and synthetic steroids adulteration in each unit and in total daily dose. Methods: Analysis of herbal products for allopathic drugs adulteration was carried out using HPLC techniques. The methods were reproduced with optimized extraction and chromatographic conditions. Calibration curves were reconstructed for validation purposes.

Results: The herbal products were adulterated with various synthetic drugs. The concentrations (mean $\pm S D$ ) were: atenolol ( $50.06 \pm 1.20 \mathrm{mg} /$ unit dose), propranolol ( $20.30 \pm 0.44 \mathrm{mg} /$ unit dose, $28.26 \pm 0.06$ $\mathrm{mg} /$ unit dose, $15.40 \pm 1.58 \mathrm{mg} / \mathrm{unit}$ dose), ACE inhibitors i.e. captopril (52.99 $\pm 0.49 \mathrm{mg} / \mathrm{unit}$ dose) and frusemide (42.02 $\pm 0.88 \mathrm{mg} / \mathrm{unit}$ dose). For the synthetic steroids, the levels (mean $\pm S D$ ) were prednisolone (13.67 $\pm 0.50 \mathrm{mg} / \mathrm{unit}$ dose), methyl prednisolone (4.18 $\pm 0.02 \mathrm{mg} / \mathrm{unit}$ dose), betamethasone ( $0.56 \pm 0.06 \mathrm{mg} / \mathrm{unit}$ dose) and dexamethasone (1.75 $\pm 0.11 \mathrm{mg} / \mathrm{unit}$ dose).

Conclusion: Administration of adulterated remedies can cause severe toxicity and is a serious safety concerns for public health. Therefore, to maximize consumer safety, appropriate rules and regulations should be developed for registration of herbal remedies.
\end{abstract}

Keywords: Herbal medicines, Adulterants, Allopathic drugs, Synthetic steroids

\begin{abstract}
This is an Open Access article that uses a funding model which does not charge readers or their institutions for access and distributed under the terms of the Creative Commons Attribution License (http://creativecommons.org/licenses/by/4.0) and the Budapest Open Access Initiative (http://www.budapestopenaccessinitiative.org/read), which permit unrestricted use, distribution, and reproduction in any medium, provided the original work is properly credited.
\end{abstract}

Tropical Journal of Pharmaceutical Research is indexed by Science Citation Index (SciSearch), Scopus, International Pharmaceutical Abstract, Chemical Abstracts, Embase, Index Copernicus, EBSCO, African Index Medicus, JournalSeek, Journal Citation Reports/Science Edition, Directory of Open Access Journals (DOAJ), African Journal Online, Bioline International, Open-J-Gate and Pharmacy Abstracts

\section{INTRODUCTION}

Hypertension is a major cause and risk factor for stroke, coronary heart diseases, disability and deaths [1,2]. The incidence of hypertension has increased globally with lower control rate [3]. Herbal medicines are considered safe, therefore gained much appreciation and are widely consumed for the treatment of hypertension [4].
A large population around the globe depends on herbal medicines to address their healthcare needs [5-7]. It is a general belief that products labeled "herbal" are always safe and non-toxic, in contrast to conventional drugs [8]. This concept has considerably increased the use of herbal medicines over the last decade, hence encouraging herbalists to treat a wide range of chronic diseases like hypertension $[7,9]$. 
In several Asian countries, particularly Pakistan, herbal medicines are commonly used and the idea about its potential toxicity is not well established [10,11]. During handling and manufacturing processes, additional particulate matters become the part of herbal medicines, since no conscious efforts are made to prevent herbal products from contamination [12]. Amplified reports on the side effects due to adulteration of herbal medicine throughout the world have raised concerns about their safety [9]. Therefore herbal medicines (raw materials and finished dosage forms) must be registered, marketed and their safety, efficacy and preclinical trial data have to be submitted to the national authority in order to ensure its safe therapeutic use [13]. This study aims the qualitative and quantitative analysis of undeclared allopathic and synthetic steroids in antihypertensive herbal products.

\section{EXPERIMENTAL}

\section{Chemicals and reagents}

Propranolol ( $\geq 99.9 \%$ purity), atenolol ( $\geq 99.36$ $\%$ purity), captopril ( $\geq 99.67 \%$ purity), frusemide $(\geq 99.44 \%$ purity), sodium bicarbonate $\left(\mathrm{NaHCO}_{3}\right)$, purity $99.95 \%$ (Fluka), diethyl ether, purity $>99.5 \%$ (Fischer Scientific, USA), ethanol (absolute) (Sigma-Aldrich, Germany), tween-80, sodium chloride, potassium chloride, disodium hydrogen phosphate, potassium di-hydrogen phosphate, dichloromethane, mannitol and distilled water. HPLC grade methanol (purity $\geq$ $99.9 \%$ ) and acetonitrile (purity $\geq 99.9 \%$ ), (Sigma-Aldrich, Germany). Ultra-pure (Deionized) water was prepared with millipore ultra-pure water system (Milford, USA).
Prednisolone $(\geq 99.9 \%$ purity $)$, methyl prednisolone ( $\geq 99.9 \%$ ), betamethasone ( $\geq 99.9$ $\%)$, dexamethasone $(\geq 99.9 \%)$, methanol ( $\geq 99.9$ $\%$ purity), acetonitrile ( $\geq 99.9 \%$ purity), acetate buffer ( $\mathrm{pH} 3.0)$.

\section{Instrumentation and chromatographic condi- tions}

The liquid chromatography (LC-10AT VP) system with an isocratic pump (SPD 10AV-VP) connected to UV/Visible detector (Schimadzo) and C18 $(150 \mathrm{~mm} \times 5 \mu \mathrm{m})$ HPLC column was used for current analysis. The chromatographic conditions for the identified drugs are summarized in Table 1.

\section{Extraction of allopathic drugs from herbal products}

An aliquot of the sample of herbal antihypertensive products was transferred to 125 $\mathrm{ml}$ separating funnel followed by $40 \mathrm{ml}$ of petroleum ether and thoroughly mixed. The resultant solution was extracted with five $20 \mathrm{ml}$ portions of alcohol petroleum ether. The extract was then evaporated to dryness in water bath and the residue was dissolved in absolute alcohol. The solution was then used for the identification of allopathic drugs while analyzing through HPLC [16].

\section{Extraction of synthetic steroids from herbal products}

Hot continuous extraction (Soxhlet) method of extraction was employed for the extraction of steroids from herbal antihypertensive products.

Table 1: Chromatographic conditions for the identified drugs

\begin{tabular}{|c|c|c|c|c|}
\hline Drug & Mobile phase composition & $\lambda-\max$ & Flow rate & Ref \\
\hline Atenolol & $10 \mathrm{mM} \mathrm{KH}_{2} \mathrm{PO}_{4}(\mathrm{pH} 6.0)$, methanol $(70: 30, v / v)$ & $225 \mathrm{~nm}$ & $1 \mathrm{~mL} \min ^{-1}$ & [14] \\
\hline Propranolol & $\begin{array}{l}\text { Acetonitrile } / 0.05 \mathrm{M} \text { ammonium phosphate monobasic } \\
(15: 85) \\
\mathrm{PH} 3.0 \text { with } \mathrm{H}_{3} \mathrm{PO}_{4}\end{array}$ & $290 \mathrm{~nm}$ & $1 \mathrm{~mL} \min ^{-1}$ & [15] \\
\hline Captopril & $\begin{array}{l}\text { Acetonitrile, deionized water and acetic acid (44:55:0.2, } \\
\mathrm{v} / \mathrm{v} / \mathrm{v}) \text {. }\end{array}$ & $258 \mathrm{~nm}$ & $1 \mathrm{~mL} \mathrm{~min}^{-1}$ & [15] \\
\hline Frusemide & $\begin{array}{l}\text { Water ( } \mathrm{pH} 3.0 \text { with } 20 \% \text { ortho-phosphoric acid) and } \\
\text { organic (58:42 v/v composed of acetonitrile and } \\
\text { methanol) in } 50: 50 \mathrm{v} / \mathrm{v} \text {. }\end{array}$ & $230 \mathrm{~nm}$ & $1 \mathrm{~mL} \min ^{-1}$ & [15] \\
\hline Prednisolone & $\begin{array}{l}\text { Water (pH } 3.0 \text { with acetate buffer) and organic (60:40 } \\
\mathrm{v} / \mathrm{v} \text { composed of acetonitrile and methanol) in 50:50 v/v. }\end{array}$ & $254 \mathrm{~nm}$ & $1 \mathrm{~mL} \min ^{-1}$ & [15] \\
\hline $\begin{array}{l}\text { Methyl } \\
\text { prednisolone }\end{array}$ & $\begin{array}{l}\text { Water ( } \mathrm{pH} 3.0 \text { with acetate buffer) and organic (60:40 } \\
\mathrm{v} / \mathrm{v} \text { composed of acetonitrile and methanol) in 50:50 v/v. }\end{array}$ & $254 \mathrm{~nm}$ & $1 \mathrm{~mL} \min ^{-1}$ & [15] \\
\hline Betamethasone & $\begin{array}{l}\text { Water (pH } 3.0 \text { with acetate buffer) and organic (60:40 } \\
\mathrm{v} / \mathrm{v} \text { composed of acetonitrile and methanol) in 50:50 v/v. }\end{array}$ & $254 \mathrm{~nm}$ & $1 \mathrm{~mL} \min ^{-1}$ & [15] \\
\hline Dexamethasone & $\begin{array}{l}\text { Water ( } \mathrm{pH} 3.0 \text { with acetate buffer) and organic }(60: 40 \\
\mathrm{v} / \mathrm{v} \text { composed of acetonitrile and methanol) in } 50: 50 \mathrm{v} / \mathrm{v} \text {. }\end{array}$ & $254 \mathrm{~nm}$ & $1 \mathrm{~mL} \min ^{-1}$ & [15] \\
\hline
\end{tabular}


Specified number of tablets of each herbal product was grounded finely and an aliquot of the powder equivalent to about $50 \mathrm{mg}$ was placed in micro Soxhlet extractor. The powder was extracted with ether for $4 \mathrm{~h}$ and the extract was than discarded. The thimble was removed and the residual petroleum was allowed to evaporate. The thimble was then returned to the Soxhlet extractor and was extracted with Chloroform for next 04 hrs using dry extraction flask. The extract was evaporated to dryness. The traces of solvent were removed at room temperature with the aid of current Air. The residue was then weighed and used for further HPLC analysis [16].

\section{Statistical analysis}

The data are presented as mean \pm standard deviation and were calculated using GraphPad Prism 5 (GraphPad Software Inc. San Diego CA, USA).

\section{RESULTS}

Various allopathic drug contents of $\beta$-blockers (atenolol and propranolol), ACE inhibitors (captopril), diuretic agent, (frusemide) and steroids were detected and calculated for total daily dose as recommended by the prescriber (Table 2 and Table 3). The standard calibration curves of identified allopathic adulterants are provided in Figure 1.
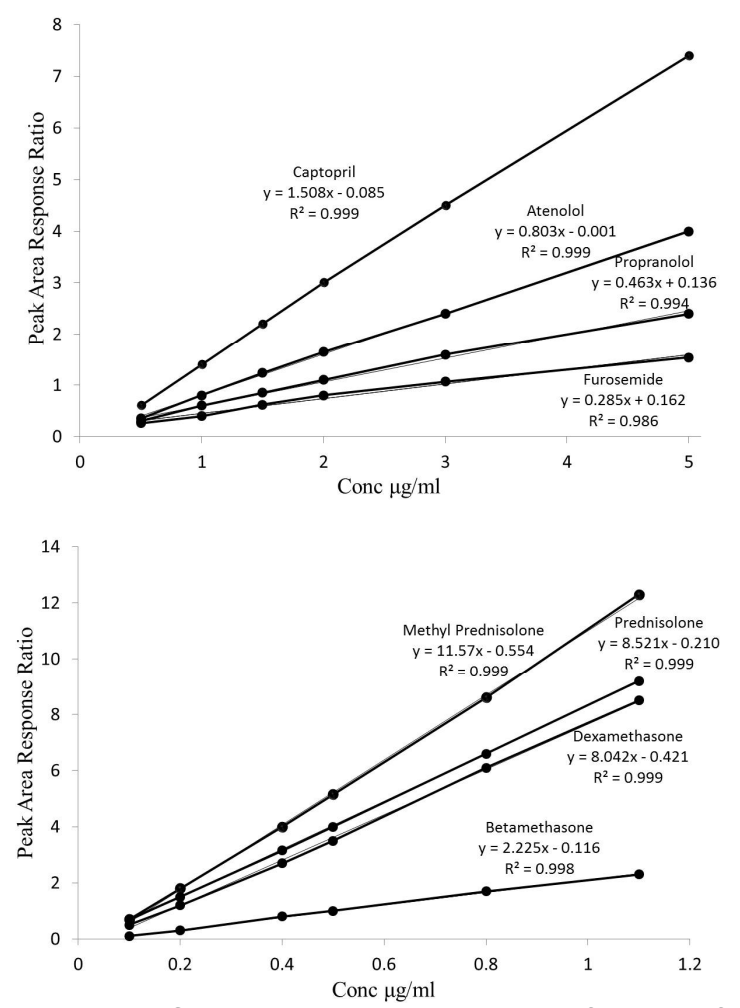

Figure 1: Standard calibration curves for identified allopathic and steroids adulterants
Figure 2, Figure 3 and Table 1 and Table 2 indicate the herbal antihypertensive products (both raw materials and finished dosage form) were adulterated with allopathic drug contents and synthetic steroids and a lot of variation was found in daily dose which may be due to greater variation in pharmaceutical quality control parameters and this often lead to toxicity or subtherapeutic effects [17]. Adulterated allopathic contents of atenolol were found in finished dosage form (tablets) of herbal antihypertensive products. Propranolol were found in different three (03) herbal products one of which is in raw material (20.30 $\pm 0.44 \mathrm{mg} / \mathrm{unit}$ dose) and the finished product of the same product of same batch was found to have no traces of propranolol. Similarly the other two products contain propranolol in finished dosage (28.26 \pm $0.06 \mathrm{mg} / \mathrm{unit}$ dose, $15.40 \pm 1.58 \mathrm{mg} / \mathrm{unit}$ dose) and the raw material after test had no allopathic contents of propranolol. Captopril (52.99 \pm 0.49 $\mathrm{mg} / \mathrm{unit}$ dose) and frusemide (42.02 \pm 0.88 $\mathrm{mg} / \mathrm{unit}$ dose) were also found in finished products in different quantities.
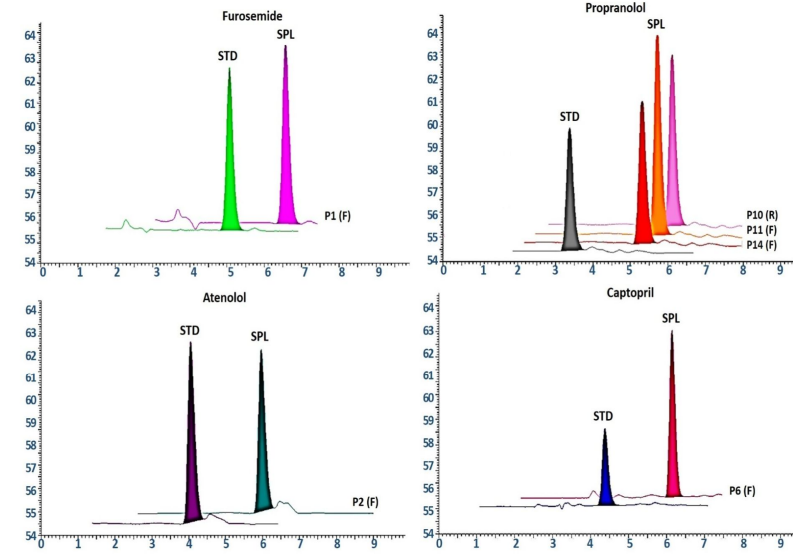

Figure 2: Overlays of standard and identified allopathic adulterants in herbal products

Synthetic steroidal contents were as follows: prednisolone $(4.18 \pm 0.50 \mathrm{mg} / \mathrm{unit}$ dose $)$, methylprednisolone (13.67 $\pm 0.02 \mathrm{mg} / \mathrm{unit}$ dose), betamethasone $(1.75 \pm 0.11 \mathrm{mg} / \mathrm{unit}$ dose $)$ and dexamethasone $(0.56 \pm 0.06 \mathrm{mg} / \mathrm{unit}$ dose). Prednisolone was detected in both the raw materials and finished drug products, while the adulterants were found only in the finished products.

All adulterated compounds were then quantified for daily intake according to the manufacturer dose. From table 2, it can be seen that the daily intake of atenolol was found (150.18 \pm 0.32 $\mathrm{mg} /$ day), propranolol in three different products administered according to manufacturer dose was found $(60.90 \pm 0.11,84.78 \pm 0.56$ and 46.20 $\pm 3.26 \mathrm{mg} /$ day). The strength of captopril (105.98 
$\pm 0.4 \mathrm{mg} /$ day $)$ and frusemide $(126.06 \pm 1.02$ $\mathrm{mg} /$ day) were as stipulated by their manufacturers. For the synthetic steroids, the manufacturers' recommended dose were prednisolone $(12.54 \pm 0.63 \mathrm{mg} / \mathrm{day})$, methylprednisolone (41.01 $\pm 0.9 \mathrm{mg} / \mathrm{day})$, betamethasone $(5.25 \pm 0.18 \mathrm{mg} /$ day $)$ and dexamethasone $(1.68 \pm 0.10 \mathrm{mg} /$ day $)$ (Table 2 and Figure 3).

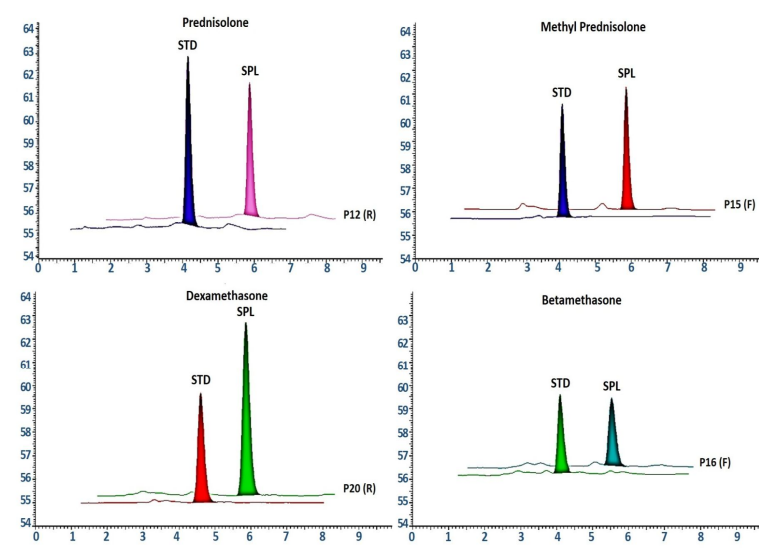

Figure 3: Overlays of standard and identified allopathic adulterants in herbal products

\section{DISCUSSION}

Most herbal products have not been scientifically evaluated; thus, information on their pharmacokinetics, pharmacodynamics, efficacy and safety are limited. Intentional and unintentional adulteration with synthetic drugs are frequently found in herbal products. The results indicate that allopathic antihypertensive and steroidal adulterants, including $\beta$-blockers, ACE inhibitors, diuretics and steroids, are present in the tested herbal medicines.

Untested and unregulated steroid containing herbal drugs are sold to the public. Due to lack of expertise, education and professionalism, the herbalists and quacks adulterate their remedies with steroids, to counter the hypertension $[18,19]$. In 2007, FDA issued nine safety alert warnings to stop using thirteen different brands adulterated with synthetic drugs. FDA issued mandatory guidelines for manufacturers to avoid contaminating products with other herbs, pesticides, heavy metals, and allopathic drugs.

Table 2: Quantified adulterated synthetic drugs in raw and finished dosage form in average per unit dose of herbal products

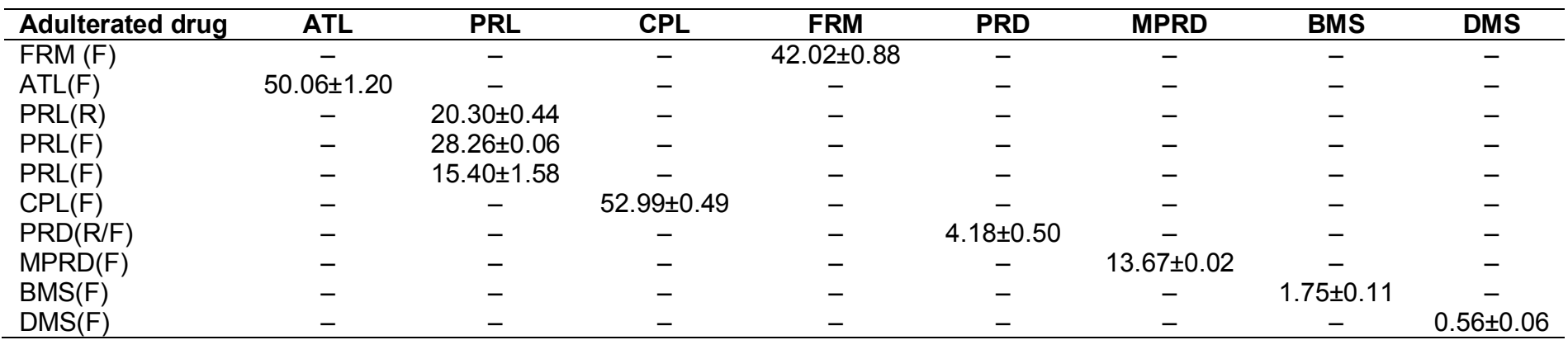

Data are presented as mean \pm standard deviation $(n=6)$. Note: $\mathrm{ATL}=$ atenolol, $\mathrm{PRL}=$ propranolol, $\mathrm{CPL}=$ captopril, $\mathrm{FRM}=$ frusemide, $\mathrm{PRD}=$ prednisolone, $\mathrm{MPRD}=$ methyl prednisolone, $\mathrm{BMS}=$ betamethasone, $\mathrm{DMS}=$ dexamethasone, $R$ = raw material, $F$ = finished dosage form

Table 3: Adulterated synthetic drugs in raw and finished dosage forms of herbal products (manufacturers' information, dose/day)

\begin{tabular}{|c|c|c|c|c|c|c|c|c|}
\hline Adulterated drug & ATL & PRL & CPL & FRM & PRD & MPRD & BMS & DMS \\
\hline FRM (F) & - & - & - & $126.06 \pm 1.02$ & - & - & - & - \\
\hline ATL $(F)$ & $150.18 \pm 0.32$ & - & - & - & - & - & - & - \\
\hline PRL(R) & - & $60.90 \pm 0.11$ & - & - & - & - & - & - \\
\hline PRL(F) & - & $84.78 \pm 0.56$ & - & - & - & - & - & - \\
\hline PRL(F) & - & $46.20 \pm 3.26$ & - & & - & - & - & - \\
\hline $\mathrm{CPL}(\mathrm{F})$ & - & - & $105.98 \pm 0.4$ & - & - & - & - & - \\
\hline $\mathrm{PRD}(\mathrm{R} / \mathrm{F})$ & - & - & - & - & $12.54 \pm 0.6$ & - & - & - \\
\hline $\operatorname{MPRD}(F)$ & - & - & - & - & - & $41.01 \pm 0.9$ & - & - \\
\hline $\mathrm{BMS}(\mathrm{F})$ & - & - & - & - & - & - & $5.25 \pm 0.18$ & - \\
\hline DMS(F) & - & - & - & - & - & - & - & $1.68 \pm 0.10$ \\
\hline
\end{tabular}

Data are presented as mean \pm standard deviation $(n=6)$. Note: $\mathrm{ATL}=$ atenolol, $\mathrm{PRL}=$ propranolol, $\mathrm{CPL}=$ captopril, $\mathrm{FRM}=$ frusemide, $\mathrm{PRD}=$ prednisolone, $\mathrm{MPRD}=$ methyl prednisolone, $\mathrm{BMS}=$ betamethasone, $\mathrm{DMS}=$ dexamethasone, $\mathrm{R}=$ raw material, $\mathrm{F}=$ finished dosage form 
The results suggest that the concentrations of synthetic drugs could cause lethal interaction and toxicity. $\beta$-Blockers, ACE inhibitors and diuretics are the drugs to be prescribed under the strict supervision of physicians because of the incidence of clinical manifestations and toxicity [20]. Adulterants in herbal products may influence toxic effects to various degrees especially in central nervous system (CNS) [2123].

Patients receiving ACE inhibitors may experience variety of adverse reactions like; angioedema involving the extremities, face, lips, tongue, larynx, anaphylactic reactions, neutropenia, myeloid hypoplasia, agranulocytosis and renal failure [24]. Nonetheless, products have been reported to be contaminated with adulterants, thus exposing consumers to risk. Unethical marketing techniques have led to false advertisements about the safety and efficacy of the herbal medicine and are advocated for treatment on the basis of unproven, word-ofmouth traditions and beliefs. In a clinical study, among patients who were attending a cardiovascular clinic for the treatment of atrial fibrillation, CHF and ischemic heart disease, about $60 \%$ indulged in concomitant use of alternative therapies. More than half (58\%) took supplements that had potential interactions with allopathic drugs [25]. There is a clear need to formulate regulatory policies for product registration of herbal products as well as enlightenment of the public and physicians on the issue of contaminants in herbal remedies, via health education, early detection and management of possible herbal toxicity [25].

\section{CONCLUSION}

The findings of this study indicate that allopathic drugs and synthetic steroids are often intentionally incorporated in herbal medicines by the herbalists or quacks in order to enhance their pharmacological and therapeutic effects. Administration of such adulterated remedies may cause severe toxicity and is, thus, of a serious safety concern for public health. Therefore, to maximize consumer safety, appropriate rules and regulations should be developed for stricter regulation of herbal remedies.

\section{DECLARATIONS}

\section{Acknowledgement}

The authors are thankful to Department of Pharmacy, University of Peshawar for providing laboratories facilities for the work.

\section{Conflict of interest}

No conflict of interest is associated with this study.

\section{Author's contribution}

We declare that this work was done by the authors named in this article and all liabilities pertaining to claims relating to the content of this article will be borne by the authors.

\section{REFERENCES}

1. Gupta R. Trends in hypertension epidemiology in India. J Hum Hypertens 2004; 18(2): 73-78.

2. Wahabi H, Alansary L, Al-Sabban A, Glasziuo P. The effectiveness of Hibiscus sabdariffa in the treatment of hypertension: A systematic review. Phytomedicine 2010; 17(2): 83-86.

3. Gallagher $M$, Perkovic V, Chalmers J. Diuretics: A modern day treatment option? (Review Article). Nephrology 2006; 11(5): 419-427.

4. Dasgupta A. Review of abnormal laboratory test results and toxic effects due to use of herbal medicines. Am J Clin Pathol 2003; 120(1): 127-137.

5. Schippmann $U$, Leaman DJ, Cunningham A. Impact of cultivation and gathering of medicinal plants on biodiversity: global trends and issues. Biodiversity and the ecosystem approach in agriculture, forestry and fisheries [monograph on the internet]. Rome 2002. Available from http://www.fao.org/docrep/005/AA010E/ AA010E00.HTM.

6. Barnes PM, Powell-Griner E, McFann K, Nahin RL. Complementary and alternative medicine use among adults: United States, 2002. Adv Data 2004; 27(343): 119.

7. Miller LG. Herbal medicinals: selected clinical considerations focusing on known or potential drug-herb interactions. Arch Intern Med 1998; 158(20): 2200-2211.

8. Sahoo N, Manchikanti P, Dey S. Herbal drugs: Standards and regulation. Fitoterapia 2010; 81(6):462-471.

9. Pelkonen O, Abass K, Wiesner J. Thujone and thujonecontaining herbal medicinal and botanical products: Toxicological assessment. Regul Toxicol Pharmacol 2013; 65(1): 100-107.

10. Chan K. Some aspects of toxic contaminants in herbal medicines. Chemosphere 2003; 52(9): 1361-1371.

11. Ko RJ, Ko R. Causes, epidemiology, and clinical evaluation of suspected herbal poisoning. J ToxicolClin Toxicol 1999; 37(6): 697-708.

12. Calixto BJ. Efficacy, safety, quality control, marketing and regulatory guidelines for herbal medicines (phytotherapeutic agents). Braz J Med Biol Res 2000; 33(2): 179-189.

13. Elgawish MS, Mostafa SM, Elshanawane AA. Simple and rapid HPLC method for simultaneous determination of 
atenolol and chlorthalidone in spiked human plasma. Saudi Pharm J 2011; 19(1): 43-49.

14. USPNF United States Pharmacopeia and National Formulary (USP 37-NF 32). Rockville, 2014; 4.

15. Stanley S, Wilhelmi B, Rodgers J, Guthrie A. Detection of corticosteroids by high-performance liquid chromatography/negative ion chemical ionization mass spectrometry using a particle beam interface. Biol Mass Spectrom 1994; 23(8): 483-491.

16. Clutter WE, Rizza RA, Gerich JE, Cryer PE. Regulation of glucose metabolism by sympathochromaffin catecholamines. Diabetes Metab Rev 1988; 4(1): 1-15.

17. Beyerstein BL, Webb IC, Chatterton JE. Sellers of "natural" products: a review of consumer protection. Sci Rev Altern Med 2004; 8(2): 37-48.

18. Ernst E. Adulteration of Chinese herbal medicines with synthetic drugs: a systematic review. J Intern Med 2002; 252(2): 107-113.

19. Huggett D, Brooks B, Peterson B, Foran C, Schlenk D. Toxicity of select beta adrenergic receptor-blocking pharmaceuticals (B-blockers) on aquatic organisms. Arch Environ Contam Toxicol 2002; 43(2): 229-235.

20. Adler LA, Angrist B, Reiter S, Rotrosen J. Neurolepticinduced akathisia: a review. Psychopharmacology (Berl) 1989; 97(1): 1-11.

21. Jefferson JW. Beta-adrenergic receptor blocking drugs in psychiatry. Arch Gen Psychiatry 1974; 31(5): 681-691.

22. Braunwald E. Expanding indications for beta-blockers in heart failure. N EnglJ Med 2001; 344(22): 1711-1712.

23. Candan F, Alagözlü $H$. Captopril inhibits the pulmonary toxicity of paraquat in rats. Hum Exp Toxicol 2001; 20(12): 637-641.

24. Small Jr W, Molteni A, Kim YT, Taylor JM, Ward WF. Mechanism of captopril toxicity to a human mammary ductal carcinoma cell line in the presence of copper. Breast Cancer Res Treat 1999; 55(3): 223-229.

25. Al-Shabanah O, Mansour M, El-Kashef H, Al-Bekairi A. Captopril ameliorates myocardial and hematological toxicities induced by adriamycin. IUBMB Life 1998; 45(2): 419-427. 